\section{Characterizing the fungal and bacterial microflora and concentrations in fitness centres}

\author{
Carla A. Ramos ${ }^{1,2}$, Carla Viegas ${ }^{3}$, Sandra Cabo Verde ${ }^{1}$, \\ Humbert T. Wolterbeek ${ }^{2}$ and Susana M. Almeida ${ }^{1}$
}

Indoor and Built Environment 2016, Vol. 25(6) 872-882 (C) The Author(s) 2015

Reprints and permissions: sagepub.co.uk/ journalsPermissions.nav DOI: $10.1177 / 1420326 \times 15587954$ ibe.sagepub.com

@AGE

\begin{abstract}
Fitness centres are special places where conditions for microbiological proliferation should be considered. Moisture due to human perspiration and water condensation as a result of human physical activities are prevalent in this type of buildings. Exposure to microbial contaminants is clinically associated with respiratory disorders and people who work out in polluted environments would be susceptible to contaminants. This work studied the indoor air contamination in three gymnasiums in Lisbon. The sampling was performed at two periods: at the opening (morning) and closing (night) of the three gymnasiums. The airborne bacterial and fungal populations were sampled by impaction directly onto Tryptic Soy Agar (for bacteria) and Malt Extract Agar (for fungi) plates, using a Merck MAS-100 air sampler. Higher bacterial concentrations were found at night as compared to the morning but the same behaviour was not found for fungal concentrations. Gram-negative catalase positive cocci were the dominant bacteria in indoor air samples of the studied gymnasiums. In this study, 21 genera/species of fungal colonies were identified. Chrysosporium sp., Chrysonilia sp., Neoscytalidium hialinum, Sepedonium sp. and Penicillium sp. were the most prevalent species identified in the morning, while Cladosporium sp., Penicillium sp., Chrysosporium sp., Acremonium sp. and Chrysonilia sp. were more prevalent at night. A well-designed sanitation and maintenance program for gymnasiums is needed to ensure healthier space for indoor physical activity.
\end{abstract}

\title{
Keywords
}

Indoor air, Bacteria, Fungi, Fitness centres

Accepted: 30 April 2015

\section{Introduction}

Within indoor air, there is a complex mixture of viable and non-viable particles. The non-viable include inorganic particles, such as metals and other chemical compounds, and organic non-reactive material. The viable components are those that are capable of growing under favourable conditions, such as bacteria, fungi and all other microorganisms. Bioaerosols are normally defined as 'particles with biological origin suspended in the air', which can cause health effects, especially in the upper airways. ${ }^{1-3}$

The indoor microbial pollution involves hundreds of species of bacteria and fungi growing inside buildings when specific conditions are favourable. The main factors that influence microbial growth in a building are moisture, temperature and nutrient availability. The ventilation rate for air renewal is also a crucial

${ }^{1}$ Centro de Ciências e Tecnologias Nucleares, Instituto Superior Técnico, Universidade de Lisboa, Bobadela, LRS, Portugal

${ }^{2}$ Faculty of Applied Sciences, Department of Radiation, Radionuclides and Reactors, Technical University of Delft, Delft, The Netherlands

${ }^{3}$ Environmental Health RG - Lisbon School of Health Technology - Polytechnic Institute of Lisbon, Lisboa, Portugal

\section{Corresponding author:}

Carla A. Ramos, Centro de Ciências e Tecnologias Nucleares, Instituto Superior Técnico, Universidade de Lisboa, Estrada Nacional 10, Km 139,7 2695-066 Bobadela LRS, Portugal.

Email: carla.ramos@ctn.ist.utl.pt 
factor for the control of microbial growth. In fitness centres, moisture due to perspiration and water condensation, marked human presence, elevated physical activity that promotes the resuspension of dust from the ground and contact between the occupants and surfaces (pavement, fitness equipment) are conditions that promote the microbial growth. Fungi are ubiquitous microorganisms that proliferate in more diverse environments due to their lower water activity $\left(a_{w}\right)$ than bacteria. Bacteria require an $\mathrm{a}_{\mathrm{w}}$ above 0.80 , while fungi present minimum $\mathrm{a}_{\mathrm{w}}$ of approximately $0.70 .{ }^{4}$ Moreover, fungi are less selective in what concerns the substrate and consequently are able to grow on a diverse range of surfaces (wood, wall paper, etc.). Combined with these conditions for growth, joins the existence of fungal spore in indoor air. These spores are easily released into the air through aerial hyphae, while in the case of bacteria this process is not easy to promote, due to its gelatinous colonies.

Exposure to microbial contaminants is clinically associated with respiratory symptoms, allergies, asthma and immune reactions ${ }^{5}$ depending upon the nature of the microbiological agent and the host's immune status. Some species of gram-negative bacteria are of most concern when present in indoor air because they are producers of endotoxins that can cause respiratory symptoms, including non-allergic asthma. ${ }^{5}$ Gram-positive bacteria represent the largest group present in the atmosphere due to their greater resistance and survival abilities. ${ }^{6,7}$ Fungi species among Aspergillus, Penicillium and Fusarium genera are producers of mycotoxins which can enter the human body by inhalation, dermal and oral contact, thereby causing different reactions in the host organism. ${ }^{8}$

Athletes and the common individual that practice sport present a higher risk of contact with bioaerosols and pollution due to the fact that

1. the minute ventilation could proportionally enhance the quantity of inhaled pollutants;

2. most of the air is inhaled through the mouth, bypassing the normal nasal mechanisms of filtration of larger particles and

3. the increased airflow velocity would carry pollutants deeper into the respiratory tract. ${ }^{9}$

However, despite the importance of healthy air in sport facilities, indoor air quality (IAQ) studies have been focused principally on schools, ${ }^{10-15}$ elderly care centres, ${ }^{16-19}$ homes $^{20}$ and offices. ${ }^{21,22}$ Comparatively, IAQ evaluations carried out in fitness centres (not school gymnasiums) are very scarce and few have been reported. ${ }^{23-26}$
The aim of this work was to assess indoor air contamination in three gymnasiums, by fungal identification and bacterial characterization, in order to estimate the potential biological hazards during sporting activity in fitness centres.

\section{Methodology \\ Sampling sites}

In this study, three gymnasiums in the city of Lisbon were selected, and termed as follows: gymnasium 1 (G1), gymnasium $2(\mathrm{G} 2)$ and gymnasium $3(\mathrm{G} 3)$. Inside the fitness centres, sampling sites were chosen: the studios and the bodybuilding rooms. In G2 and G3, only the studio with the most practicing fitness classes was monitored, whereas in G1, two studios were evaluated. As described in Table 1, all fitness centres have identical location besides having a different surrounding. All fitness centres have mechanical ventilation; however, G2 preferentially uses natural ventilation rather than mechanical ventilation as it was observed that it was often switched off. The sampling campaigns were performed between October and December of 2012.

\section{Air sampling}

Samples were collected in two periods of the day - in the morning and at night (at the opening and closing of the gymnasium)-in order to recognize the differences before and after occupancy. Air samples were collected at the centre of the studied room, on ground level.

Air sampling was conducted using a microbial air sampler (MAS-100, Merck Millipore, Germany) that collected, by impaction, $0.25 \mathrm{~m}^{3}$ of air in each plate, with a flow rate of $6 \mathrm{~m}^{3} / \mathrm{h}$. Two different culture media were used in order to provide to the microorganisms the most suitable nutrients for their growth: Malt Extract Agar (supplemented with $0.1 \mathrm{~kg} / \mathrm{m}^{3}$ chloramphenicol), used for fungi, and Tryptic-Soy Agar, used for bacteria. Tryptic-Soy Agar is a general agar medium used for culturing many kinds of non-fastidious and moderately fastidious microorganisms. ${ }^{27}$ The sampling was also performed outdoors to compare the results between the indoor and the outdoor environments. The samples were sealed with parafilm and transported to the laboratory in a cooler bag. Air sample culture plates were incubated at $30^{\circ} \mathrm{C}$ between 5 and 7 days (Memmert oven, Germany). A total of 48 Petri dishes with bacterial colonies and 48 Petri dishes with fungal colonies were analyzed. The colony counts were corrected using the positive hole correction table MAS-100, provided by the supplier. ${ }^{28}$ The microbiological concentrations were expressed in colonies forming units per cubic metre (CFU.m $\left.{ }^{-3}\right)$. 


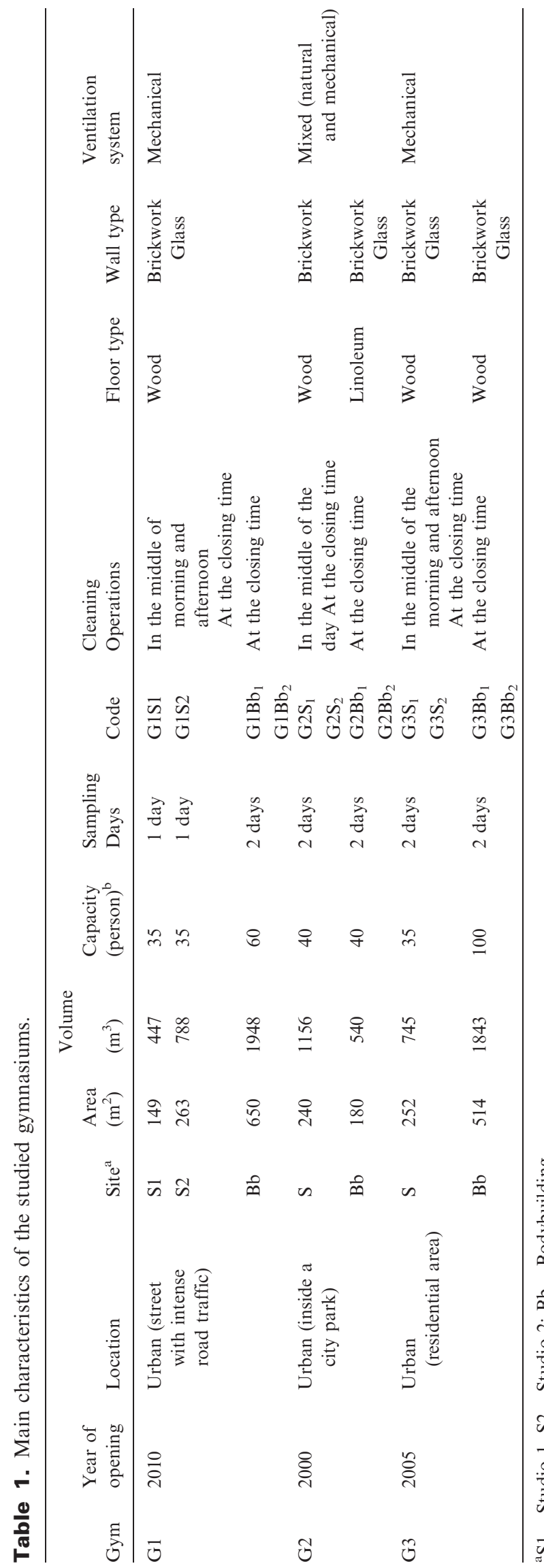

A Greywolf (IAQ 610, WolfSense Solutions, USA) was used to continuously monitor the comfort parameters (temperature, relative humidity and $\mathrm{CO}_{2}$ ) inside the rooms during the sampling days, from the opening to closing of the gymnasiums. ${ }^{23}$ Outdoor meteorological data were obtained from Aeroporto weather station located in the centre of Lisbon $\left(38^{\circ} 46^{\prime} \mathrm{N}, 9^{\circ} 08^{\prime} \mathrm{W}\right)$, from which data are available online. ${ }^{29}$ MAS-100 and Greywolf were calibrated according to fabricant specifications.

\section{Microbial characterization}

Fungal colonies were grouped by macroscopic colony characteristics (e.g. colour, shape and elevation). For fungal identification, microscopic mounts were performed using tease mount or Scotch tape mount and lactophenol cotton blue mount procedures. ${ }^{30}$ Morphological identification was achieved through macro and microscopic characteristics as given by de Hoog et al. ${ }^{31}$

The obtained bacterial isolates were characterized based on their macroscopic traits (e.g. pigmentation, texture and shape), microscopic morphology (cellular morphology, and presence/absence of endospores) and biochemical characteristics (gram staining, catalase and oxidase activities). For the morphological characterization, bacteria were isolated in Tryptic-Soy Agar medium and incubated at $30^{\circ} \mathrm{C}$ for $24 \mathrm{~h}$. The isolates were grouped into morphological types based on their characteristics. The definition of the morphological types was based on the Bergey's Manual of Determinative Bacteriology. ${ }^{32}$ The frequency of each morphological type was calculated based on the number of isolates obtained and on their characters.

\section{National guidelines for bioaerosols}

In Portugal, a recent legislation established new limit values for microbiological contamination in indoor environments, ${ }^{33}$ replacing the previous diploma. ${ }^{34}$ In the previous legislation, a critical limit of $500 \mathrm{CFU} \cdot \mathrm{m}^{-3}$ was defined as the threshold for bacteria and fungi concentrations. Currently, the legal compliance is different concerning the type of microorganism. For fungi, indoor concentrations should be less than outdoor concentrations; and for bacteria, the indoor concentration should not exceed the outdoor concentration by 350 CFU.m ${ }^{-3}$. However, when these situations are not fulfilled, there is a second opportunity to satisfy the legal requirements according to Tables 2 and 3.

$\approx$. The critical limit of $500 \mathrm{CFU} \cdot \mathrm{m}^{-3}$ was applied in guidelines and other studies. ${ }^{33-37}$ In this present study, the sampling campaigns were performed when the previous legislation was in force, therefore the previous legislation limit was used to determine the legal 
Table 2. Portuguese legal compliance for microbiological parameters according to Portaria no. 353-A/2013.

\begin{tabular}{|c|c|c|}
\hline & Fungi & Bacteria \\
\hline 1st requirement & - [indoor $]<$ [outdoor $]$ & - $[$ indoor $]+350 \mathrm{CFU} . \mathrm{m}^{-3}<$ [outdoor $]$ \\
\hline $\begin{array}{l}\text { 2nd requirement (to be } \\
\text { applied when the } 1 \text { st } \\
\text { requirement is not } \\
\text { fulfilled) }\end{array}$ & $\begin{array}{l}\text { - No visible fungal growth } \\
\text { on surfaces; } \\
\text { - Species should be } \\
\text { evaluated according Table } 3\end{array}$ & $\begin{array}{l}\text { - }[\text { indoor }]+350 \mathrm{CFU} \cdot \mathrm{m}^{-3}>\text { [outdoor] } \\
\text { and }\left[\mathrm{CO}_{2}\right]<1800 \mathrm{mg} \cdot \mathrm{m}^{-3} ; \\
\text { - Ratio between Gram-negative bacteria } \\
\text { and total bacteria should be less than } 0.5 \text {. }\end{array}$ \\
\hline
\end{tabular}

Table 3. Fungal conformity based on the species according to Portaria no. 353-A/2013.

\begin{tabular}{|c|c|c|}
\hline Species & & Specific condition of conformity \\
\hline Common species & $\begin{array}{l}\text { Cladosporium spp } \\
\text { Penicillium spp } \\
\text { Aspergillus spp } \\
\text { Alternaria spp } \\
\text { Eurotium spp } \\
\text { Paecilomyces spp } \\
\text { Wallemia spp.. }\end{array}$ & Mixture of species: $\leq 500$ CFU.m ${ }^{-3}$ \\
\hline Non-common species & $\begin{array}{l}\text { Acremonium spp } \\
\text { Chrysonilia spp } \\
\text { Tricothecium spp } \\
\text { Curvularia spp } \\
\text { Nigrospora spp }\end{array}$ & $\begin{array}{l}\text { One specie: }<50 \text { CFU.m }{ }^{-3} \\
\text { Mixture of species: }<150 \text { CFU.m }\end{array}$ \\
\hline Pathogenic species & $\begin{array}{l}\text { Chryptococcus neoformans } \\
\text { Histoplasma capsulatum } \\
\text { Blastomyces dermatitidis } \\
\text { Coccidioides immitis }\end{array}$ & Absence of any species \\
\hline Toxigenic species & $\begin{array}{l}\text { Stachybotrys chartarum } \\
\text { Aspergillus versicolor } \\
\text { Aspergillus flavus } \\
\text { Aspergillus ochraceus } \\
\text { Aspergillus terreus } \\
\text { Aspergillus fumigatus } \\
\text { Fusarium moniliforme } \\
\text { Fusarium culmorum } \\
\text { Trichoderma viride }\end{array}$ & One specie: $<12$ CFU.m ${ }^{-3}$ (Several colonies per plate) \\
\hline
\end{tabular}

compliance; and we also consider the compliance with the new limit requirements.

\section{Statistical analysis}

The Origin $7.5^{\circledR}$ software was used to compute graphical figures and the Statistica ${ }^{\circledR}$ software was used to calculate the statistical tests.

\section{Results and discussion \\ Comfort parameters}

According to the comfort criteria defined by the ISO $7730: 2005,{ }^{38}$ the temperature should range between $23^{\circ} \mathrm{C}$ and $26^{\circ} \mathrm{C}$ and the relative humidity should vary between $30 \%$ and $70 \%$. Table 4 presents the temperature and relative humidity measured in the three fitness centres during the sampling campaigns. Temperature varied between $10^{\circ} \mathrm{C}$ and $27^{\circ} \mathrm{C}$ with the greatest humidity levels recorded/observed in G1 (80\%), exceeding the comfort criteria defined by ISO 7730:2005. The highest values for these parameters were recorded during occupancy of the spaces. ${ }^{38}$

$\mathrm{CO}_{2}$ concentration was used not only as an indicator of ventilation efficiency, comfort and excess of occupancy but also to evaluate the microbiological compliance according to the Portuguese legislation. Table 4 shows the variation of indoor $\mathrm{CO}_{2}$ concentrations measured during the sampling campaigns. $\mathrm{CO}_{2}$ varied 
Table 4. Physical parameters measured outdoor and indoor (temperature and relative humidity) and indoor $\mathrm{CO}_{2}$ measured in fitness centres.

\begin{tabular}{|c|c|c|c|c|c|c|}
\hline \multirow[b]{2}{*}{$\begin{array}{l}\text { Fitness } \\
\text { centre }\end{array}$} & \multirow[b]{2}{*}{$\begin{array}{l}\text { Sampling } \\
\text { site }\end{array}$} & \multicolumn{2}{|l|}{ Outdoor } & \multicolumn{3}{|l|}{ Indoor } \\
\hline & & $\begin{array}{l}\text { Temperature } \\
\left({ }^{\circ} \mathrm{C}\right) \\
\bar{x} \pm \sigma\end{array}$ & $\begin{array}{l}\text { Relative } \\
\text { humidity (\%RH) } \\
\bar{x} \pm \sigma\end{array}$ & $\begin{array}{l}\text { Temperature } \\
\left({ }^{\circ} \mathrm{C}\right) \\
\bar{x} \pm \sigma\end{array}$ & $\begin{array}{l}\text { Relative } \\
\text { humidity (\%RH) } \\
\bar{x} \pm \sigma\end{array}$ & $\begin{array}{l}\mathrm{CO}_{2}\left(\mathrm{mg} \cdot \mathrm{m}^{-3}\right) \\
\bar{x} \pm \sigma\end{array}$ \\
\hline \multirow[t]{3}{*}{ G1 } & Studio 1 & $19 \pm 3.2$ & $70 \pm 15$ & $18 \pm 0.88$ & $80 \pm 4.1$ & $1147 \pm 502$ \\
\hline & Studio 2 & & & $19 \pm 1.01$ & $78 \pm 5.2$ & $1315 \pm 591$ \\
\hline & Bodybuilding & & & $19 \pm 0.35$ & $72 \pm 2.6$ & $1882 \pm 553$ \\
\hline \multirow[t]{2}{*}{ G2 } & Studio & $17 \pm 2.4$ & $61 \pm 8.2$ & $23 \pm 1.7$ & $58 \pm 7.07$ & $1185 \pm 587$ \\
\hline & Bodybuilding & & & $21 \pm 1.3$ & $59 \pm 7.8$ & $1015 \pm 219$ \\
\hline \multirow[t]{2}{*}{ G3 } & Studio & $9.6 \pm 2.3$ & $64 \pm 11$ & $20 \pm 1.1$ & $69 \pm 5.2$ & $1122 \pm 289$ \\
\hline & Bodybuilding & & & $20 \pm 1.1$ & $57 \pm 5.6$ & $1456 \pm 355$ \\
\hline
\end{tabular}

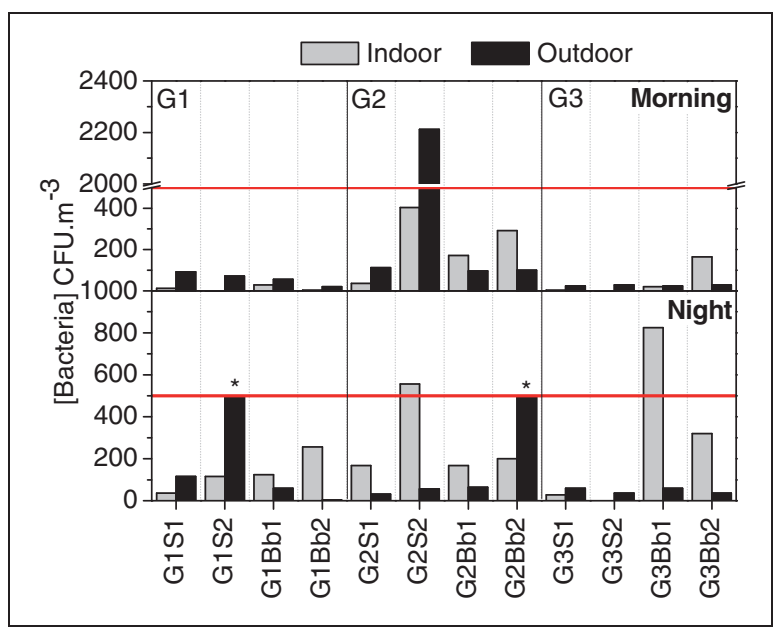

Figure 1. Concentrations of airborne bacteria measured indoors and outdoors of studied fitness centres. Results provided for each sampling site and sampling period. The horizontal line indicates the critical limit of 500 CFU.m ${ }^{-3}$. The * indicates that the number of colonies were countless and therefore a concentration above $500 \mathrm{CFU} \cdot \mathrm{m}^{-3}$ was assumed.

between $398 \mathrm{mg} \cdot \mathrm{m}^{-3}$ and $3590 \mathrm{mg} \cdot \mathrm{m}^{-3}$ and showed a strong correlation between high occupancy and HVAC systems. ${ }^{23}$ Higher $\mathrm{CO}_{2}$ concentrations were observed during periods of physical activities within the studios.

\section{Total bacteria and fungi concentrations}

Figures 1 and 2 illustrate the indoor and outdoor concentrations of bacteria and fungi in the fitness centres.

Bacterial concentrations exceed the outdoor concentrations by $350 \mathrm{CFU} \cdot \mathrm{m}^{-3}$ during the night period in the studio of $\mathrm{G} 2$ in the second day of sampling (556 CFU. $\mathrm{m}^{-3}$ indoor and 56 CFU. $\mathrm{m}^{-3}$ outdoor) and

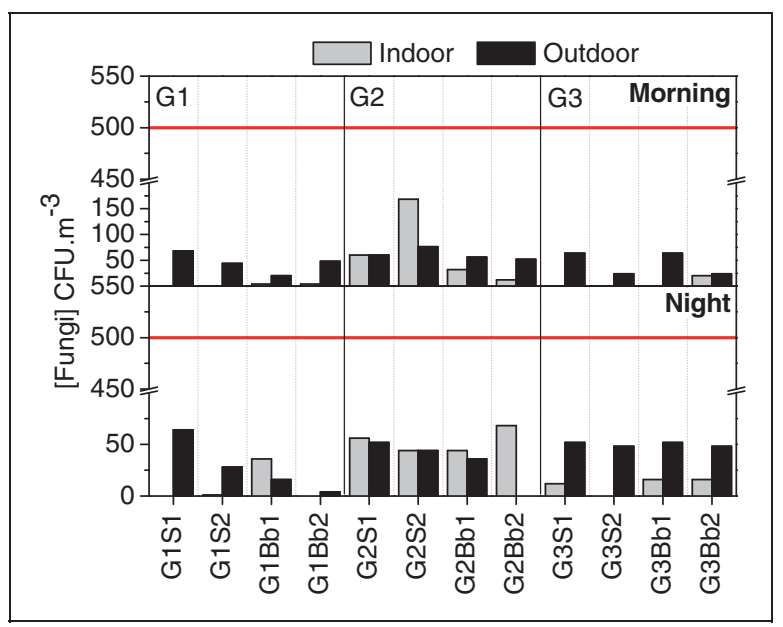

Figure 2. Concentrations of airborne fungi measured indoors and outdoors of studied fitness centres. Results provided for each sampling site and sampling period. The horizontal line indicates the critical limit of $500 \mathrm{CFU} . \mathrm{m}^{-3}$.

in the bodybuilding room of $\mathrm{G} 3$ in the first day of sampling $\left(824 \mathrm{CFU} \cdot \mathrm{m}^{-3}\right.$ indoor and $60 \mathrm{CFU} \cdot \mathrm{m}^{-3}$ outdoor). In the above situations, the critical limit of 500 CFU. ${ }^{-3}$ was also exceeded. Results showed that at the end of the day, the bacterial load was significantly higher indoors than outdoors, indicating the effect of occupants on bacterial development.

For fungal concentrations, indoor concentrations were greater than outdoor concentrations in G2 in six measurements (sampling performed in the studio during the morning period and in all sampling performed at the end of the day) and in G1 in the bodybuilding room at night. Regarding the old guidelines, ${ }^{33}$ the critical limit value of $500 \mathrm{CFU} \cdot \mathrm{m}^{-3}$ was not exceeded in any situation. Results show that the highest 


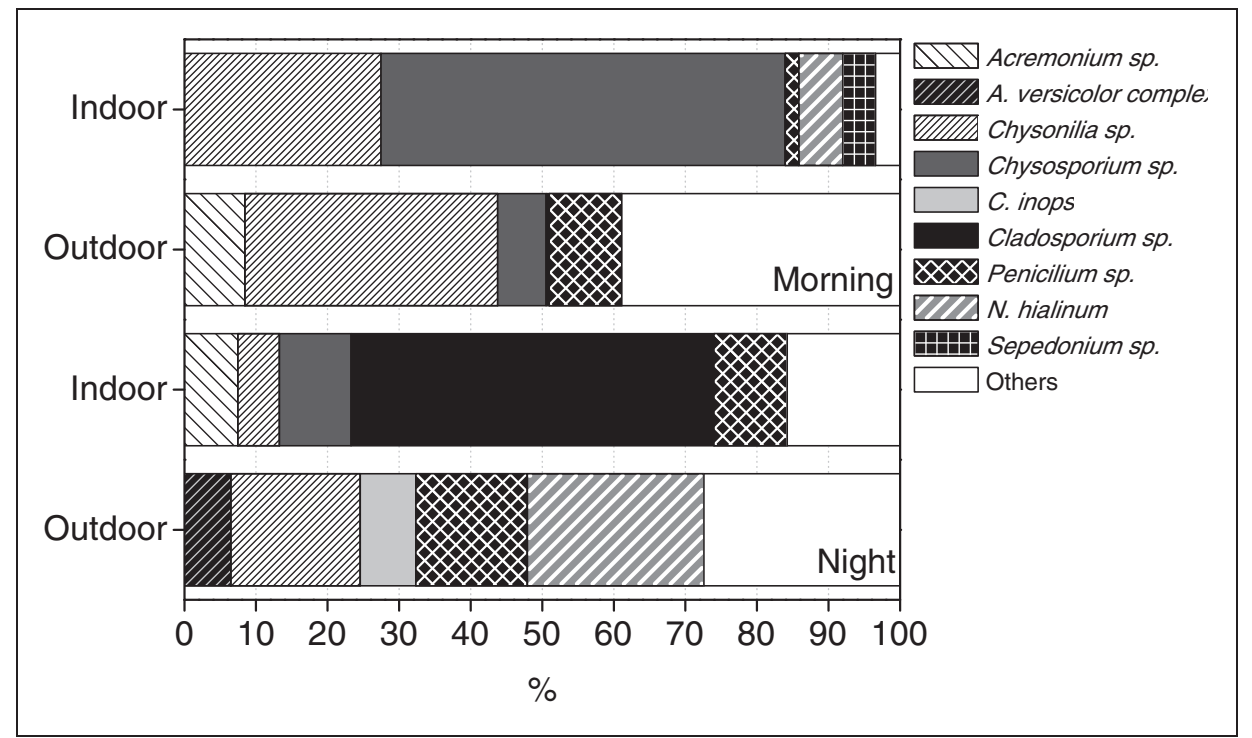

Figure 3. Frequency of the five most prevalent fungal genera in the two periods of sampling (morning and night), both indoors and outdoors.

concentrations were registered in G2 where there was natural ventilation, a phenomena which was also observed by Frankel et al. ${ }^{39}$ In G1 and G3, outdoor particles were retained in the filters that were placed in the Air Treatment Units in both buildings, whereas in G2, outdoor air enters through the window spaces without any filtration. Moreover, G1 and G3 have mechanical ventilation, which is more efficient in promoting pollutant dilution. ${ }^{40}$

In general, there was an increase in bacterial load at night that was not observed with fungi. This suggests that the bacteria are more associated with human occupancy than fungi. The presence of bacteria indoors might be associated with deposited dust, ${ }^{41}$ skin cells and hair. ${ }^{42}$ These results are in agreement with that presented by Dacarro et al. $^{43}$ concerning the microbial load in universities and school gyms during physical education classes.

\section{Identification of fungal species}

The identification of fungal species is very important for the study of fungal contamination since it allows the differentiation between benign and harmful species. $^{31,44,45}$

As presented in Figure 3, indoors, Chrysosporium sp. represented $56 \%$ of the fungal genera found in the air sample in the morning, the presence was reduced to $10 \%$ in the air sample taken at night, while $51 \%$ of the night time sample was identified as Cladosporium sp. The prevalence of Chrysonilia sp. was reduced from $27 \%$ in the morning to $5.8 \%$ before the closing time of the gym, and same behaviour was found outdoors, reducing the prevalence from $35 \%$ to $18 \%$. The indoor Penicillium sp. was found to have increased from $1.9 \%$ to $10 \%$ between the two studied periods; this increase was also found in the outdoor samples $(10 \%$ to $16 \%$ ). Acremonium sp. was only identified indoors at the end of the day $(7.5 \%)$. In fact, the most prevalent fungal genera found by our study are also consistent with other studies. Cladosporium sp. was widely found as the dominant genera inside buildings in many work. ${ }^{46-50}$ Regarding sports facilities, a study conducted in a sports hall in China indicated that the dominant genera indoors were Cladosporium sp., Penicillium sp., Aspergillus sp. and Alternaria sp., making up $95 \%$ of the total observed genera. ${ }^{51}$ Viegas et al. $^{24}$ described Cladosporium sp. as the principal isolated genera in a gymnasium, followed by Penicillium sp., Aspergillus sp., Mucor sp., Phoma sp. and Crysonilia sp. In a study conducted in houses in Barcelona, the greatest indoor concentrations of Cladosporium sp. was found during autumn; ${ }^{.2}$ the same trend was also found in infant bedrooms in the USA. ${ }^{53}$ Species of Cladosporium sp. are widely distributed, commonly encountered on all kinds of plants and on debris and are frequently isolated from soil, food, paint, textiles and other organic matter, ${ }^{54}$ therefore justifying the high prevalence of this fungi indoors at the end of the day because of the passage of debris from outdoors to indoors by people throughout the day.

A total of 22 genera and 27 species of fungal colonies were identified by this study. Table 5 shows the fungal species found indoors and outdoors of the fitness centre, during the two periods of sampling. Significant statistical differences were found in relation to the indoor and outdoor concentrations of fungal species, 
Table 5. Distribution of fungal species indoor and outdoor in the two periods of sampling (morning and night). In bold are the five most prevalent fungal species identified in the morning $(\mathrm{M})$ and at night $(\mathrm{N})$, both indoors and outdoors.

\begin{tabular}{|c|c|c|c|c|c|c|c|c|c|c|c|c|}
\hline \multirow[b]{3}{*}{ Colonies } & \multicolumn{4}{|c|}{ G1 } & \multicolumn{4}{|l|}{ G2 } & \multicolumn{4}{|l|}{ G3 } \\
\hline & \multicolumn{2}{|c|}{ Indoor } & \multicolumn{2}{|c|}{ Outdoor } & \multicolumn{2}{|c|}{ Indoor } & \multicolumn{2}{|c|}{ Outdoor } & \multicolumn{2}{|c|}{ Indoor } & \multicolumn{2}{|c|}{ Outdoor } \\
\hline & M & $\mathrm{N}$ & M & $\mathrm{N}$ & M & $\mathrm{N}$ & M & $\mathrm{N}$ & M & $\mathrm{N}$ & M & $\mathrm{N}$ \\
\hline A. flavus complex & & & & & & & & 4 & & & & \\
\hline A. fumigatus complex & 4 & & 11 & 4 & & & & & & & 8 & 8 \\
\hline A. niger complex & & & 4 & & & & 4 & & & & & \\
\hline Circumdati complex & & & & & & & & & & & & 8 \\
\hline A. ustus complex & & & & & & & & & & 4 & & \\
\hline A. versicolor complex & & & & 20 & & & & & & & & \\
\hline Acremonium sp. & & & & & & 36 & 20 & 8 & & & 40 & \\
\hline Alternaria sp. & & & & & & & & 24 & & 4 & 16 & \\
\hline Aureobasidium sp. & & & & 12 & & & & & & 4 & 16 & 8 \\
\hline Botrytis sp. & & & & & & & 4 & & & & & \\
\hline Chrysonilia sp. & & & 35 & 12 & 72 & 28 & 56 & 32 & & & 24 & 24 \\
\hline Chrysosporium sp. & & & 4 & & 148 & 48 & 28 & & & & & 4 \\
\hline C.inops & & & 4 & 16 & & & & 8 & & & & \\
\hline Cladosporium sp. & & & 8 & & & 244 & & & & & & 4 \\
\hline Eurotium $s p$. & & & & & & & 4 & & & & & \\
\hline Fusarium poae & & & & & & & 8 & & & & & \\
\hline Geotrichum sp. & & & & 16 & & 12 & 8 & & & 4 & & \\
\hline Mucor sp. & & & & 4 & & 8 & & 16 & & & & \\
\hline Neoscytalidium $s p$. & & & & & & 8 & 12 & & & & & \\
\hline$N$. dimidiatum & & & & & & 4 & 4 & & & & & \\
\hline N. hialinum & & & & 8 & 16 & 4 & 28 & 32 & & 8 & & 56 \\
\hline Paecilomyces sp. & & & & & & & & & & & 24 & \\
\hline Penicillium sp. & 4 & 9 & & & 4 & 24 & 20 & 4 & 20 & 16 & 48 & 88 \\
\hline Phoma sp. & & & & & & 4 & & 4 & & & & \\
\hline Rhodotorula sp. & & & & 4 & 4 & 8 & 12 & & & & & \\
\hline Scedosporium $s p$ & & & 4 & & & & 32 & & & & & \\
\hline Scopulariopsis sp. & & & & & 4 & & & & & & & \\
\hline S. brevicaulis & & & & & & & & & & 4 & & \\
\hline Sepedonium $s p$ & & & & & 12 & & & & & & & \\
\hline Syncephalastrum racemosum & & & & & 12 & & & & & & & \\
\hline Total & 8 & 9 & 70 & 96 & 272 & 428 & 240 & 132 & 20 & 44 & 176 & 200 \\
\hline
\end{tabular}

for G1 and G3 (Wilcoxon Matched Pairs test, G1, $p=0.03 ; \mathrm{G} 2, p=0.89 ; \mathrm{G} 3, p=0.01)$, although no significant statistical differences were found between the indoor concentrations among gymnasiums (MannWhitney test, $p=1$ for all tests). In G1, two fungal species were identified (Penicillium sp. and one belonging to A. fumigatus complex), while in G2, 12 different genera and three species were found (Acremonium sp., Chrysonilia sp., Chrysosporium sp., Cladosporium sp., Penicillium sp., Geotrichum sp., Mucor sp., Neoscytalidium sp., $N$. dimidiatum, $N$. hialinum,
Rhodotorula sp., Sepedonium sp., Syncephalastrum recemosum, Scopulariopsis sp., Phoma sp.). In G3, seven species were identified (one belonging to $A$. ustus complex, Alternaria sp., Aureobasidium sp., Geotrichum sp., Penicillium sp., S. brevicaulis, N. hialinum). As observed, the fungal load in G2 was higher than in other fitness centres. This can be explained by the fact that in G1 and G3, the fungi that come from outdoors are retained in the filters, whereas in G2, outdoor air enters in the rooms by the windows without any filtration. As emphasized in the studies of Frankel 
Table 6. Frequencies of the isolated morphological groups (\%).

\begin{tabular}{|c|c|c|c|c|c|c|}
\hline \multirow[b]{2}{*}{ Morphological type } & \multicolumn{2}{|l|}{ G1 } & \multicolumn{2}{|l|}{ G2 } & \multicolumn{2}{|l|}{ G3 } \\
\hline & I & $\mathrm{O}$ & I & $\mathrm{O}$ & I & $\mathrm{O}$ \\
\hline Gram-positive, catalase-positive cocci & 3.2 & 5.1 & 0.11 & & 1.7 & \\
\hline Gram-negative, catalase-positive cocci & 25 & 58 & 30 & 55 & 30 & 38 \\
\hline Gram-negative, catalase-negative cocci & 1.4 & & & & 48 & 38 \\
\hline Non-spore forming, Gram-positive, catalase-positive bacilli & 0.13 & 3.4 & & & & \\
\hline Non-spore forming, Gram-positive, catalase-negative bacilli & 2 & & 0.16 & & & 6.3 \\
\hline Gram-negative, oxidase-positive bacilli & & 8.5 & 0.05 & 5.8 & & \\
\hline Gram-negative, oxidase-negative bacilli & 1.2 & 25 & & 20 & 20 & 19 \\
\hline
\end{tabular}

et al. $^{39}$ and Kemp et al., ${ }^{45}$ outdoor air is the main source of indoor fungi in healthy buildings.

Toxic species were found in G1 and G3 indoors, such as Aspergillus genus, belonging to A. fumigatus complex, ${ }^{55-59}$ which is considered to be an indicator of moisture-damaged buildings. ${ }^{60}$ Other most notable toxic mould belongs to A. ustus complex.

Fungal identification revealed one potentially dangerous situation (defined according Table 3 ) in the G2 studio associated with the presence of Chrysonilia sp. with a concentration of $72 \mathrm{CFU} . \mathrm{m}^{-3}$. Chrysonilia $\mathrm{sp}$. is considered a non-common species and is known to induce asthma. ${ }^{61-63}$ In all the assessed gymnasiums, no sign of fungal growth was detected on the walls, furniture or in other materials.

Concerning the colonies concentration found indoor, there was a higher concentration found in the morning than at night that resulted in seven new species in $\mathrm{G} 2$ and six new species in G3. Some of these new isolates (A. ustus complex, Acremonium sp., Alternaria sp., Aureobasidium sp., Cladosporium sp., Geotrichum sp., Mucor sp., Neoscytalidium sp., N. hialinum, Phoma sp. and $S$. brevicaulis) can produce toxic compounds (metabolites or mycotoxins), though few of their metabolites have been shown to be produced in natural indoor environments. ${ }^{8}$

\section{Bacteria characterization}

Phenotypic characterization of the most prevalent isolates, collected by impaction in TSA medium, allowed for the identification of seven morphological groups, as summarized in Table 6.

Observing bacterial morphology and the Gram reaction usually constitutes the first stage of identification and is very useful for the preliminary identification of bacterial species. The traditional methods that employ observation of either single cell morphology or colony characteristics remain reliable parameters for the identification of bacterial species and still have significant taxonomic value. ${ }^{64}$ Therefore, and despite being described by several authors as old fashioned, bacterial morphological characterization can provide valuable insights into individual microbial diversity, derived from both genetic and reversible changes. ${ }^{65}$ Several morphotypes have been identified in bacteria related to chronic and acute infections, and specific phenotypic traits are important clinical features. ${ }^{66-68}$

According to the national legislation, when indoor concentrations exceed the outdoor concentrations by $350 \mathrm{CFU} . \mathrm{m}^{-3}$, the ratio between the Gram-negative and the total bacteria should be less than 0.5 . In the second day of sampling in G2 studio 2, the concentration of Gram-negative bacteria was calculated to be 540 CFU.m ${ }^{-3}$ in a total of 556 CFU.m ${ }^{-3}$, resulting in a ratio of 0.9 . In $\mathrm{G} 3$ bodybuilding room 1 , the concentration of Gram-negative bacteria was calculated to be 632 CFU.m ${ }^{-3}$ in a total of 824 CFU.m ${ }^{-3}$, giving a ratio of 0.7 . Therefore, both locations failed to comply with the national legal compliance.

Our results have indicated that Gram-negative, catalase-positive cocci were the most prevalent airborne bacterial morphological-type indoors $(25 \%$ in $\mathrm{G} 1,30 \%$ in $\mathrm{G} 2$ and $30 \%$ in G3) and outdoors (55\% in G1, 30\% in G2 and $38 \%$ in G3) of all fitness centres. In a study of cultivable airborne bacteria by the US Environmental Protection Agency in the Building Assessment Survey and Evaluation (BASE), ${ }^{69}$ Gram-negative cocci were also found to be present within office buildings. The main source of Gram-negative bacteria is from settled dust, ${ }^{70}$ brought into fitness centres by users, with the concentration of indoor particles affected by the levels of human occupancy. ${ }^{41,71,72}$ Contamination can also be caused by outdoor particles due to the high prevalence of Gram-negative cocci. The second most prevalent bacterial phenotype was the Gram-positive, catalase positive cocci, appearing indoors in all the three studied gymnasiums. Several studies indicated that this phenotype is the most prevalent morphological type indoors. ${ }^{28,70,73,74}$ This phenotype includes species such 
as Staphylococcus and Micrococcus, which are abundant on human skin and on mucous membranes. ${ }^{74,75}$ Our results were similar to those found by Bouillard et al. $^{70}$ in healthy office buildings once Gram-positive catalase negative cocci were not identified. G1 presented the highest morphological diversity when compared with the other fitness centres. As bacteria are strongly linked with levels of human occupancy, this result can be related to the higher occupancy of G1 and the need of more effective sanitation. This difference can be attributed to the higher levels of human occupancy within this gymnasium, as there is a strong correlation between human occupancy and bacterial diversity, revealing the need for more effective sanitation.

\section{Conclusions}

The indoor microflora is a complex mixture that varies according to the activities being undertaken, human occupancy levels, ventilation systems and physical parameters such as temperature and humidity. This work studied the microbiological load present in three fitness centres in the city of Lisbon, with results showing the existence of critical situations due to the presence of dangerous and toxic fungal species indoors. Natural ventilation used in $\mathrm{G} 2$ could have an influence on indoor fungal concentrations as no physical barrier exists to filter the outdoor air. For bacteria, nonconformities were recorded in $\mathrm{G} 2$ and G3. An increase in indoor bacterial concentration was observed during the evening that was not observed for fungal concentrations, thereby demonstrating the effect of human occupancy in the building on bacterial load.

\section{Authors' contribution}

All authors contributed equally in the preparation of this paper.

\section{Acknowledgments}

The authors gratefully acknowledge the fitness centres that collaborated in this study and also Fundação para a Ciência e Tecnologia (FCT) for funding the PhD grant SFRH/BD/79277/2011. C $\mathrm{C}^{2} \mathrm{TN} / \mathrm{IST}$ authors gratefully acknowledge the FCT support through the UID/Multi/ $04349 / 2013$ project.

\section{Declaration of conflicting interests}

The author(s) declared no potential conflicts of interest with respect to the research, authorship and/or publication of this article.

\section{Funding}

The author(s) disclosed receipt of the following financial support for the research, authorship, and/or publication of this article: This research received no specific grant from any funding agency in the public, commercial, or not-for-profit sectors.

\section{References}

1. Bünger J, Antlauf-Lammers M, Schulz T, Westphal G, Müller M, Ruhnau $\mathrm{P}$ and Hallier E. Health complaints and immunological markers of exposure to bioaerosols among biowaste collectors and compost workers. Occup Environ Med 2000; 57: 458-464.

2. Heldal K, Halstensen AS, Thorn J, Djupesland P, Wouters I, Eduard W and Halstensen TS. Upper airway inflammation in waste handlers exposed to bioaerosols. Occup Environ Med 2003; 60: 444-450.

3. Eduard W and Halstensen A. Quantitative exposure assessment of organic dust. SJWEH Suppl 2009; 7: 30-35.

4. Beuchat L, Komitopoulu E, Beckers H, Betts R, Bourdichon F, Fanning S, Joosten HM and Ter Kuile BH. Low-water activity foods: increased concern as vehicles of foodborne pathogens. J Food Protect 2013; 76(1): 150-172.

5. WHO. WHO guidelines for indoor air quality: dampness and mould. Copenhagen: World Health Organization (WHO), 2009.

6. Fang Z, Ouyang ZY, Hu LF, Wang X and Hu L. Culturable airborne bacteria in outdoor environments in Beijing, China. Microb Ecol 2007; 54: 487-496.

7. Shaffer BT and Lighthart B. Survey of airborne bacteria at four diverse locations in Oregon: urban, rural, forest and coastal. Microb Ecol 1997; 34: 167-177.

8. Jarvies B and Miller J. Mycotoxins as harmful indoor air contaminants. Appl Microbiol Biot 2005; 66: 367-372.

9. Carlisle A and Sharp N. Exercise and outdoor ambient air pollution. Brit J Sport Med 2001; 35(4): 214-222.

10. Canha N, Almeida SM, Freitas MC, Wolterbeek HT, Cardoso J, Pio CA and Caseiro A. Impact of wood burning on indoor $\mathrm{PM}_{2.5}$ in a primary school in rural Portugal. Atmos Environ 2014; 94 : 663-670.

11. Canha N, Almeida M, Freitas MC and Almeida SM. Seasonal variation of total particulate matter and children respiratory diseases at Lisbon basic schools using passive methods. Proc Environ Sci 2011; 4: 170-183.

12. Canha N, Almeida-Silva M, Freitas MC, Almeida SM and Wolterbeek HT. Lichens as biomonitors at indoor environments of primary schools. J Radioanal Nucl Ch 2012; 291(1): 123-128.

13. Canha N, Martinho M, Almeida-Silva M, Freitas MC, Almeida SM, Pegas PN, Alves C, Pio CA, Trancoso MA, Sousa R, Mouro $\mathrm{F}$ and Contreiras $\mathrm{T}$. Indoor air quality in primary schools. Int $J$ Environ Pollut 2012; 50(1-4): 396-410.

14. Canha N, Almeida SM, Freitas MC and Wolterbeek HT. Indoor and outdoor biomonitoring using lichens at urban and rural primary schools. J Toxicol Env Heal A 2014; 77: 14-16. (900-915.

15. Almeida SM, Canha N, Silva A, Freitas MC, Pegas PN and Alves C. Children exposure to air particulate matter in indoor of Lisbon primary schools. Atmos Environ 2011; 45(40): 7594-7599.

16. Almeida-Silva M, Almeida SM, Pegas PN, Nunes T, Alves CA and Wolterbeek HT. Exposure and dose assessment to particle components among an elderly population. Atmos Environ 2015; 102: $156-166$.

17. Almeida-Silva M, Wolterbeek HT and Almeida SM. Elderly exposure to indoor air pollutants. Atmos Environ 2014; 8: 54-63.

18. Almeida-Silva M, Almeida SM, Gomes JF, Albuquerque PC and Wolterbeek HT. Determination of airborne nanoparticles in elderly care centers. J Toxicol Env Heal A 2014; 77(14-16): 867-878.

19. Viegas C, Almeida-Silva M, Gomes AQ, Wolterbeek HT and Almeida SM. Fungal contamination assessment in Portuguese elderly care centers. J Toxicol Env Heal A 2014; 77(1-3): 14-23. 
20. Osman LM, Douglas JG, Garden C, Reglitz K, Lyon J, Gordon $\mathrm{S}$ and Ayres JG. Indoor air quality in homes of patients with chronic obstructive pulmonary disease. Am J Resp Crit Care 2007; 176: 465e72.

21. Bluyssen PM, Fernandes ED, Groes L, Clausen G, Fanger PO, Valbjorn O, Bernhard CA and Roulet CA. European indoor air quality audit project in 56 office buildings. Indoor Air 1996; 6: $221 \mathrm{e} 38$.

22. Almeida SM, Freitas MC, Reis M, Pinheiro T, Felix P and Pio CA. Fifteen years of nuclear techniques application to suspended particulate matter studies. J Radioanal Nucl Ch 2013; 297(3): 347-356

23. Ramos CA, Almeida SM and Wolterbeek HT. Exposure to indoor air pollutants during physical activity in fitness centers. Build Environ 2014; 82: 349-360.

24. Viegas C, Alves C, Carolino E, Rosado L and Santos CS. Prevalence of fungi in indoor air with reference to gymnasiums with swimming pools. Indoor Built Environ 2010; 19(5): 555-561.

25. Viegas C, Alves C, Carolino E, Pinheiro C, Rosado L and Santos CS. Assessment of fungal contamination in a group of Lisbon's gymnasiums with a swimming pool. Italian Assoc Industr Hygien 2011; 2(1): 15-20.

26. Onchang $R$ and Panyakapo $M$. The physical environments and microbiological contamination in three different fitness centres and the participants' expectations: Measurement and analysis. Indoor Built Environ 2014; 1420326X14543209.

27. Nunes I, Mesquita N, Cabo Verde S, Bandeira A, Carolino M, Portugal A and Botelho ML. Characterization of an airborne microbial community: a case study in the archive of the University of Coimbra, Portugal. Int Biodeter Biodegr 2013; 79: 36-41.

28. Li CS. Sampling performance of impactors for bacterial bioaerossols. Aerosol Sci Tech 1999; 30(3): 280-287.

29. Russia's Weather server. Weather Archive - World, Europe. Obtained from: http://meteo.infospace.ru/wcarch/html/index.sht (accessed 27 September 2014).

30. Fischer F and Cook NB. Fundamentals of diagnostic mycology. Philadelphia, PA: Saunders Company, 1998.

31. de Hoog C, Guarro J, Gené G and Figueiras M. Atlas of clinical fungi. 2nd ed. Ultrecht: Centraalbureau voor Schimmelcultures, 2000.

32. Holt JG. Bergey's manual of determinative bacteriology. 9th ed. Baltimore: Williams \& Wilkins, 1994.

33. Portaria no. 353-A/2013. Requisitos de ventilação e qualidade do ar interior. Ministérios do Ambiente, Ordenamento do Território e Energia, da Saúde e da Solidariedade, Emprego e Segurança Social, Lisbon, 2013.

34. Decreto-Lei no. 79/2006. Regulamento dos Sistemas Energéticos de Climatização em Edifícios (RSECE). Ministério das Obras Públicas. Transportes e Comunicações, Lisbon, 2006.

35. ACGIH. Guidelines for the assessment of bioaerosols in the indoor environment. Cincinnati: American Conference of Governmental Industrial Hygienists, 1989.

36. Reynolds SJ, Streifel AJ and Mcjilton CE. Elevated airborne concentrations of fungi in residential and office environments. Am Ind Hyg Assoc J 1990; 51(71): 601-604.

37. The Government of Hong Kong. A guide on indoor air quality certification scheme for offices and public spaces, 2003: http:// www.iaq.gov.hk/cert/doc/CertGuide-eng.pdf (accessed 15 March 2014).

38. ISO 7730:2005. Ergonomics of the thermal environment - analytical determination and interpretation of thermal comfort using calculation of the PMV and PPD indices and local thermal comfort criteria. Geneva: International Organization for Standardization, 2005.
39. Frankel M, Beko G, Timm M, Gustavsen S, Hansen E and Madsen A. Seasonal variations of indoor microbial exposures and their relation to temperature, relative humidity and air exchange rate. Appl Environ Microb 2012; 78(23): 8289-8297.

40. Canha N, Almeida SM, Freitas MC, Täubel M and Hänninen O. Winter ventilation rates at primary schools: comparison between Portugal and Finland. J Toxicol Env Heal A 2013; 76(6): 400-408

41. Hospodsky D, Qian J, Nazaroff W, Yamamoto N, Bibby K, Rismani-Yazdi $\mathrm{H}$ and Peccia J. Human occupancy as a source of indoor airborne bacteria. PLoS One 2012; (4): 1-10.

42. Clark RP. Skin scales among airborne particles. J HygieneCambridge 1973; 72: 47-51.

43. Dacarro C, Picco A, Grisoli P and Rodolfi M. Determination of aerial microbiological contamination in scholastic sports environments. J Appl Microbiol 2003; 95: 904-912.

44. Rao C, Burge $\mathrm{H}$ and Chang J. Review of quantitative standards and guidelines for fungi in indoor air. J Air Waste Manage 1996; 46: 899-908.

45. Kemp PC, Neumeister-Kemp HG, Murray F and Lysek G. Airborne fungi in non-problem buildings in a southernhemisphere mediterranean climate: preliminary study of natural and mechanical ventilation. Indoor Built Environ 2002; 11(1): 44-53.

46. Jafta N, Batterman SA, Gqaleni N, Naidoo R and Robins TG. Characterization of allergens and airborne fungi in low and middle-income homes of primary school children in Durban, South Africa. Am J Ind Med 2012; 55: 1110-1121.

47. Baxi SN, Muilenberg ML, Rogers CA, Sheehan WJ, Gaffin J, Permaul P, Kopel LS, Lai PS, Lane JP, Bailey A, Petty CR, Fu C, Gold DR and Phipatanakul W. Exposures to molds in school classrooms of children with asthma. Indoor Air 2003; 13(1): 53-64.

48. Celtik C, Okten S, Aydogdu H, Bostancioglu M, Ekuklu G, Asan $\mathrm{A}$ and Yazicioglu M. Investigation of indoor molds and allergic diseases in public primary schools in Edirne city of Turkey. Asian Pac J Allergy 2011; 29(1): 42-49.

49. Soleimani Z, Goudarzi G, Naddafi K, Sadeghinejad B, Latifi SM, Parhizgari N, Alavi N, Babaei AA, Akhoond MR, Khaefi M, Rad HD, Mohammadi MJ and Shahsavani A. Determination of culturable indoor airborne fungi during normal and dust event days in Ahvaz, Iran. Aerobiologia 2013; 9(2): 279-290.

50. Oliveira M, Ribeiro H, Delgado JL and Abreu I. Aeromycological profile of indoor and outdoor environments. J Environ Monitor 2009; 11: 1360-1367.

51. Xie H, Gan XA and Ma F. Characteristics of bacterial and fungal aerosol in gymnasia in China. Proc Int Conf Energy Environ Technol 2009; 3: 19-23.

52. de Ana SG, Torres-Rodríguez JM, Ramírez EA, García SM and Belmonte-Soler J. Seasonal distribution of Alternaria, Aspergillus, Cladosporium and Penicillium species isolated in homes of fungal allergic patients. J Invest Allerg Clin 2006; 16(6): 357-363.

53. Ren P, Jankun TM, Belanger K, Bracken MB and Leaderer BP. The relation between fungal propagules in indoor air and home characteristics. Allergy 2001; 56(5): 419-424.

54. Bensch K, Braun U, Groenewald JZ and Crous PW. The genus Cladosporium. Stud Mycol 2012; 72: 1-401.

55. Land CJ, Sostaric B, Fuchs R, Lundstrom H and Hult K. Intratracheal exposure of rats to Aspergillus fumigatus spores isolated from sawmills in Sweden. Appl Environ Microb 1989; 55: $2856-2860$.

56. Orciuolo E, Stanzani M, Canestraro M, Galimberti S, Carulli G, Lewis R, Petrini M and Komanduri KV. Effects of Aspergillus fumigatus gliotoxinand methylprednisolone on human 
neutrophils: implications for the pathogenesis of invasive aspergillosis. J Leukocyte Biol 2007; 82: 839-848.

57. dos Santos VM, Dorner JW and Carreira F. Isolation and toxigenicity of Aspergillus fumigatus from moldy silage. Mycopathologia 2003; 156: 133-138.

58. El-Shanawany AA, Mostafa ME and Barakat A. Fungal populations and mycotoxins in silage in Assiut and Sohag governorates in Egypt, with a special reference to characteristic aspergilli toxins. Mycopathologia 2005; 159: 281-289.

59. Fischer G, Muller T, Ostrowski R and Dott W. Mycotoxins of Aspergillus fumigatus in pure culture and in native bioaerosols from compost facilities. Chemosphere 1999; 38: 1745-1755.

60. Samson RA, Flannigan B, Flannigan ME, Verhoeff AP, Adan OCG and Hoekstra ES. Air quality monographs. Health implications of fungi in indoor air environments. Vol 2, Amsterdam, The Netherlands: Elsevier Publications, 1994, pp.531-538.

61. Francuz B, Yera H, Geraut L, Bensefa-Colas L, Nghiem ZH and Choudat D. Occupational asthma induced by Chrysonilia sitophila in a worker exposed to coffee grounds. Clin Vaccine Immunol 2010; 17: 1645-1646.

62. Monzón S, Gil J, Ledesma A, Ferrer L, San Juan S and Abós T. Occupational asthma IgE mediated due to Chrysonilia sitophila in coffee industry. Allergy 2009; 64(11): 1686-1687.

63. Tarlo SM, Wai Y, Dolovich J and Summerbell R. Occupational asthma induced by Chrysonilia sitophila in the logging industry. J Allergy Clin Immun 1996; 97(6): 1409-1413.

64. Tshikhudo P, Nnzeru R, Ntushelo K and Mudau F. Bacterial species identification getting easier. Afr J Biotechnol 2013; 12(41): 5975-5982.

65. Sousa AM, Machado I, Nicolau A and Pereira MO. Improvements on colony morphology identification towards bacterial profiling. J Microbiol Meth 2013; 95: 327-335.

66. Proctor RA, von Eiff C, Kahl BC, Becker K, McNamara P, Herrmann $M$ and Peters G. Small colony variants: a pathogenic form of bacteria that facilitates persistent and recurrent infections. Nat Rev Microbiol 2004; 4: 295-305.

67. Hogardt M and Heesemann J. Adaptation of Pseudomonas aeruginosa during persistence in the cystic fibrosis lung. Int $\mathrm{J} \mathrm{Med}$ Microbiol 2000; 300: 557-562.

68. Hilmi D, Parcina M, Bode K, Ostrop J, Schuett S, Heeg K, Ziebuhr W, Sommerburg $\mathrm{O}$ and Bekeredjian-Ding I. Functional variation reflects intra-strain diversity of Staphylococcus aureus small colony variants in the host-pathogen interaction. Int J Med Microbiol 2013; 303: 61-69.

69. Tsai FC and Macher JM. Concentrations of airborne culturable bacteria in 100 large US office buildings from the BASE study. Indoor Air 2005; 15(9): 71-81.

70. Bouillard L, Michel O, Dramaix M and Devleeschouwer M. Bacterial contamination of indoor air, surfaces, and settled dust, and related dust endotoxin concentrations in healthy office buildings. Ann Agr Env Med 2005; 12: 187-192.

71. Canha N, Almeida SM, Freitas MC, Trancoso M, Sousa A, Mouro F and Wolterbeek HT. Particulate matter analysis in indoor environments of urban and rural primary schools using passive sampling methodology. Atmos Environ 2014; 83: 21.

72. Almeida-Silva M, Almeida SM and Wolterbeek HT. Multi-elemental characterization of indoor aerosols in elderly care centers. J Radioanal Nucl Ch 2014; 300(2): 679-684.

73. di Giulio M, Grande R, Di Campli E, Di Bartolomeo S and Cellini L. Indoor air quality in university environments. Environ Monit Assess 2010; 170: 509-517.

74. Aydogdu H, Asan A and Otkun MT. Indoor and outdoor bacteria in child day-care centers in Edirne cuty (Turkey), seasonal distribution and influence of meteorological factors. Environ Monitor Assess 2010; 164: 53-66.

75. Fox A, Harley W, Feigley C, Salzberg D, Toole C, Sebastian A and Larsson L. Large particles are responsible for elevated bacterial marker levels in school air upon occupation. $J$ Environ Monitor 2005; 7: 450-456. 